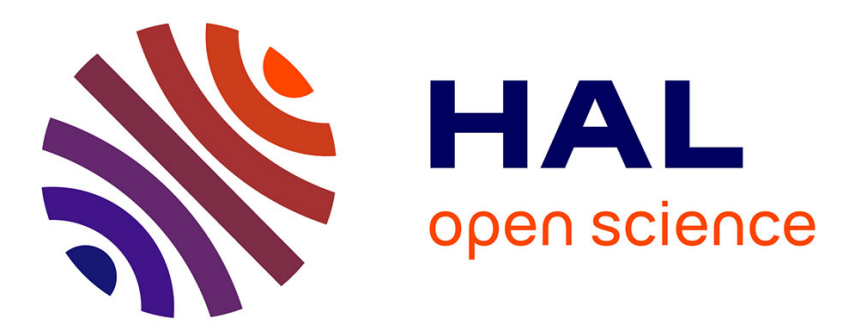

\title{
Erratum : Spectral diffusion decay of spontaneous echoes in disordered systems
}

R. Maynard, R. Rammal, R. Suchail

\section{To cite this version:}

R. Maynard, R. Rammal, R. Suchail. Erratum: Spectral diffusion decay of spontaneous echoes in disordered systems. Journal de Physique Lettres, 1980, 41 (24), pp.614-614. 10.1051/jphyslet:019800041024061400 . jpa-00231859

\section{HAL Id: jpa-00231859 https://hal.science/jpa-00231859}

Submitted on 1 Jan 1980

HAL is a multi-disciplinary open access archive for the deposit and dissemination of scientific research documents, whether they are published or not. The documents may come from teaching and research institutions in France or abroad, or from public or private research centers.
L'archive ouverte pluridisciplinaire HAL, est destinée au dépôt et à la diffusion de documents scientifiques de niveau recherche, publiés ou non, émanant des établissements d'enseignement et de recherche français ou étrangers, des laboratoires publics ou privés. 


\section{Erratum}

Spectral diffusion decay of spontaneous echoes in disordered systems

R. Maynard, R. Rammal and R. Suchail

(J. Physique Lett. 41 (1980) L-291).

Replace in equations (10), (11) and (12) 2.635 by

$7.328=8 G$ where $G$ is the Catalan's constant.

(15) should be read

$$
T_{2}=\frac{8.3 \times 10^{-2} \hbar}{C_{\mathrm{rms}} \mu_{\mathrm{A}} \mu_{\mathrm{B}} n_{0} k_{\mathrm{B}} T} .
$$

